\title{
Benchmarking a sister city: Identifying value-adding activities in Tehran compared to Seoul
}

\section{Evaluación comparativa de una ciudad hermana: Identificación de actividades de valor agregado en Teherán en comparación con Seúl}

\author{
University of Tehran, Tehran, Iran \\ ID $1^{\text {st }}$ Author: Hamid, Padash / ORC ID: 000-0001-7967-059X \\ ID $1^{\text {st }}$ Coauthor: Mehdi, Ebrahimzadeh / ORC ID: 0000-0002-7647-382X \\ ID $2^{\text {nd }}$ Coauthor: Bahman Khodapanah / ORC ID: 0000-0002-2433-3921
}

PADASH, Hamid $\dagger^{*}$, EBRAHIMZADEH, Mehdi and KHODAPANAH, Bahman

DOI: $10.35429 /$ EJM.2019.22.10.1.13

Received: December 30, 2018; Accepted: February 12, 2019

\begin{abstract}
Using employment statistics based on economic activity groups, the present study was to benchmark the economic status of Seoul (South Korea) to Tehran (Iran). Comparing both cities, it was observed that Tehran had a big gap with its benchmark (Seoul) in terms of seven activity groups including accommodation and food service activities, administrative and support service activities; professional, scientific, and technical activities; information and communication activities, real estate activities, human health and social work activities, as well as financial and insurance ones. Moreover, the contribution of these activity groups to national gross domestic product was reported significant. Thus, with the use of comparative research methodology for this research, it was found that improving these activities could help Tehran claim a much better stance in the network of global cities. In this respect, Tehran's policy makers were recommended to have a special focus on these activity groups. Also, it was suggested to monitor these activity groups on a yearly basis in order to track the changes and identify the new ones. Indeed, Tehran would approach to its benchmark position in the network of global cities by reflecting on these activities and promoting them to fill the gaps between itself and the benchmark city.
\end{abstract}

Benchmarking, Economic Activity Group, Seoul, Tehran, Value-Adding Activities

\section{Resumen}

Utilizando estadísticas de empleo basadas en grupos de actividad económica, el presente estudio fue para comparar el estado económico de Seúl (Corea del Sur) a Teherán (Irán). Al comparar ambas ciudades, se observó que Teherán tenía una gran brecha con su punto de referencia (Seúl) en términos de siete grupos de actividades que incluyen actividades de alojamiento y servicios de comida, actividades administrativas y servicios de apoyo; actividades profesionales, científicas y técnicas; Actividades de información y comunicación, actividades inmobiliarias, salud humana y actividades de trabajo social, así como financieras y de seguros. Por otra parte, la contribución de estos grupos de actividad al producto interno bruto nacional fue significativa. Por lo tanto, con el uso de una metodología de investigación comparativa para esta investigación, se encontró que mejorar estas actividades podría ayudar a Teherán a reclamar una posición mucho mejor en la red de ciudades globales. A este respecto, se recomendó a los responsables políticos de Teherán que se centraran especialmente en estos grupos de actividades. Además, se sugirió monitorear estos grupos de actividades anualmente para rastrear los cambios e identificar los nuevos. De hecho, Teherán se acercaría a su posición de referencia en la red de ciudades globales al reflexionar sobre estas actividades y promoverlas para llenar los vacíos entre ella y la ciudad de referencia.

Benchmarking, Grupo de Actividad Económica, Seúl, Teherán, Actividades de Valor Agregado

Citación: PADASH, Hamid, EBRAHIMZADEH, Mehdi and KHODAPANAH, Bahman. Benchmarking a sister city: Identifying value-adding activities in Tehran compared to Seoul. ECORFAN Journal-Mexico. 2019, 10-22: 1-13.

\footnotetext{
* Correspondence to Author (padash@ut.ac.ir)

$\dagger$ Researcher contributing first Author.
} 


\section{Introduction}

Over the last decades, urban development has turned into one of the most significant elements of economic growth in the minds of urban policy-makers (Pierre, 2016; Ahmed, 2018; Wojcik, 2018). Moreover, the European Commission has chosen a set of comprehensive policies as a growth engine for European cities. Economic development and urbanization have been also closely correlated (Kirkby, 2018). In other words; although urbanization, per se, does not act as a mechanism of economic growth, sustainable economic development cannot arise without urbanization (Henderson, 2010).

Certainly, it should be noted that urban areas have, in principle, their own unique features; and for this reason, they may face with unique threats and opportunities (Ahmed, 2018). Considering the differences between various urban areas, the policy of "one size fits all" cannot be appropriate in many cases. In fact, an increasing demand is being developed based on the "spatial" policy which implies the need to shed light on differences in urban areas (FreireGibb \& Nielsen, 2011).

Moreover, urbanization is regarded as one of the most important accelerators of productivity and economic growth. Until the 1980s, there was a negative and pessimistic attitude to expanding megacities across the world. Then, this view changed by the influence of globalization and increasing expansion of communications. In fact, a deep synergy between economic globalization and urban agglomeration can be considered as a driving factor both for the renaissance of cities in the industrialized world and for rapid urbanization (Sunley et al., 2017).

In the early 21 st century, hiring knowledge workers has grown into an essential ingredient of urban competitiveness strategies. The given strategies are often on the basis of theories claiming that cities need to attract highly skilled talents to stay or become economically successful. Indeed, talents move to places where there are job offers (Bontje, et al., 2017). Nevertheless; the role of cities is much more important as a determining power due to changes in economic contexts as well as prevalence of 'knowledge-based economy' and 'cultural economy' (ibid).
With regard to the current growth rate, urban population would rise up to 5.2 billion by 2050 , which is almost about $66 \%$ of the world's population. In 2030, Chinese cities would be home to 1 billion people. Economic potentials brought about by increased productivity, which are regarded as outcomes of urbanization, might also facilitate the processes of value creation throughout national economy via creating innovative and modern technologies and infrastructures (Floater, Rode, \& Robert, 2014).Whereas, cities with weak management probably confront with significant economic losses. Dispersion in urban areas, low-quality transportation infrastructure, and lack of basic and underlying services like energy and water supply can similarly limit accesses, so that no regional and foreign investors would like to work with such systems (Floater, Rode, \& Robert, 2014; Sassen, 2018).

Today, the destiny of nations is dependent on the performance of their cities at national and international levels (Sassen, 2018). In fact, cities are recognized as the engines of socio-economic development as well as the link between national and international development. Currently, "global network of cities" has been proposed in which the destiny of nations and cities is depended on how they operate and compete in this network. Nowadays, cities can have new functions with the following characteristics:

1. Tendency towards development of knowledge-based economy,

2. Diversity in work and activity centers, and

3. Increased role of socio-economic planning and management (Trettin \& Welter, 2011).

Some decades ago, the main role of big cities mostly consisted of industrial, trading, and administrative activities within a national scale (Bhowmik, 2012). Nowadays, together with these activities, other ones such as science and technology research, information and knowledge creation, educational services, travel services, etc. can be included (O'sullivan, 2007; Evans, 2009; Caragliu, 2011). The existing economic potentials can also lead to the formation of vibrant markets and fertile environments for innovation in the domain of ideas through increasing the productivity of the processes which are by themselves the results of the concentration of population in cities and their economic activities (Wiewel \& Perry, 2015). 
Tehran, as the capital city and the largest city in Iran in terms of population, is known as the economic center of the country. About $30 \%$ of Iran's public-sector workforce and $45 \%$ of its large industrial firms are also located in this city (Tehran Municipality, 2016). Nevertheless, this city has not yet succeeded in terms of achieving a favourable international position. In 2016 Global Cities Report, Tehran was ranked 118th among 125 cities (Kearney, 2016). According to neoclassical school of thought, growth around a steady state is determined by the rates of physical capital accumulation, population growth, and exogenous technological progress (Solow, 1956). Mehrara and Rezaei (2015) studied about the "determinants of economic growth in Iran" and indicated that the ratio of oil revenue to GDP is the most important variable affecting economic growth in the economy. In addition, there are some other variables including the ratio of imported capital and intermediate goods to GDP as well as the labor force, which play a vital role in Iran GDP growth.

Mehrara and Rezaei noted that factors such as formation of human capital, do not play a considerable role in growth process (Mehrara \& Rezaei, 2015). This situation means that Iran's economic growth is not endogenous. Hence, it has to shift from a traditional management to smart and entrepreneurial approaches for further development (Sriram, Mersha, \& Herron, 2007). To this end, there is a necessity to promote its innovative infrastructures and modern technologies via the creation of appropriate platforms for entrepreneurship and to enhance the prosperity of local and national economies through openness and the creation of innovative infrastructures and modern technologies (Healey, 2008).

Despite some studies into Tehran's economic position among regional and global cities, no comprehensive and significant results have been provided for all the facts about this capital city. Thus, the present study was an attempt to explore value-adding activities in urban areas and to identify some activities playing a catalytic role in the economic growth of cities. In this regard, Seoul was considered as a benchmark city. Accordingly; in the second section of this study, theoretical reviews as well as previous works were examined; and after that, in the third section, research method was discussed, and finally some strategies for policymakers were suggested.

ISSN-Print: 2007-1582- ISSN-On line: 2007-3682 ECORFAN $^{\circledR}$ All rights reserved.

\section{Literature review}

Kulenovic and Cech (2015) noted that economically successful cities can be found in all world regions and within many different kinds of countries - whether they are highly centralized or decentralized; whether their income level is high, low, or moderate; and whether they are perpetually at peace or still recovering from natural or manmade disasters. Moreover; successful cities can be landlocked or maritime, endowed or not with amenities and natural resources, culturally diverse or homogeneous, and also administratively consolidated or fragmented (Haila, 2000; Henderson, 2010; Kulenovic \& Cech, 2015). In addition, successful cities can be examples of highly inclusive growth or studies in terms of contrasts between the haves and the have-nots. In other words, they can reflect the contemporary planet of city dwellers, in all its complexities and contradictions (Kulenovic \& Cech, 2015).

Recently, economists have focused on creative cities as well as the importance of creativity in the composition of activities and jobs for achieving economic growth (Acs, Bosma, \& Sternberg, 2008). In this regard, the main growth engine of global cities (active metropolises) can be dependent on their potentials in the domains of knowledge-based economy and the production and distribution of globally superior services. According to Trettin and Welter (2011), this process has led to the transformation of the structure and the function of urban areas. The most important activities in this domain are:

A. Diversifying the activities of urban centers.

B. Expanding the functions of urban centers at national and international levels.

C. Restructuring urban business districts from one-functional structures to multifunctional ones

Metropolises can also have inevitably a wide variety of old and modern urban centers with different functions, scales, and spatial forms (O'sullivan, 2007). In this respect, location theories also seek to explain the distribution of activities in space aimed to identify factors influencing the location of activities, allocation of different portions of territory among various types of productions, division of spatial markets among producers, and functional distribution of activities (Capello, 2011).

PADASH, Hamid, EBRAHIMZADEH, Mehdi and KHODAPANAH, Bahman. Benchmarking a sister city: Identifying value-adding activities in Tehran compared to Seoul. ECORFAN Journal-Mexico. 2019. 
Accordingly, activities in urban centers can be divided into several main groups:

- Centers of economic activities (manufacturing, distribution, transportation, company offices, etc.)

- Historical, cultural, and tourist centers (historical places, markets, memorials, etc.)

- Advanced and superior service centers (financial, legal, educational, communication, medical, etc.)

- Scientific, artistic, and sport centers (research institutes, theaters and cinemas, museums, stadiums, etc.)

- Political, administrative, and diplomatic centers (government bodies, international institutions, embassies, etc.)

- National and international communication centers (airports, terminals, media, telecommunications, etc.) (Trettin \& Welter, 2011).

\section{Benchmarking}

For a country, a city is considered as a home for its population and most of its industries, especially service industries (Wojcik, 2018). In a global arena, cities are taken into account as representatives of a country or an economy (O'sullivan, 2007; Bhowmik, 2012). In this context, cities are also continually competing for a higher stance in the global network of economies. In this respect, benchmarking is one way to claim a stance for newly entered cities into this global network (Dick \& Narang, 2005). In addition, benchmarking is known as a process measuring performance using specific indicators that are comparable across different entities (Atkinson \& Wu, 2017). It is also recognized as a process measuring performance using specific indicators that are comparable across different entities (Meares, Owen, Murray, Mohammadzadeh, \& Rohani, 2015).

According to Business Dictionary, benchmarking refers to "a measurement of the quality of an organization's policies, products, programs, strategies, etc., and their comparison with standard measurements, or similar measurements of its peers" (Business Dictionary, 2017). Originally, benchmarking is related to businesses.
However, it can be also used for cities because of similarities between urban administration and business one. Moreover, city benchmarking can be conceptualized as measuring and monitoring the performance of cities against a number of comparable and/or 'best practice' cities (SGSEP, 2009). However, four types of benchmarking studies have been suggested by Taylor including business costoriented studies, livability-oriented studies, performance-oriented studies, and inter-sectorial studies (Taylor, 2011).

\section{Research Method}

This study was to identify some applicable value-adding activities to Tehran as the capital city of Iran. In this study, international benchmarking of cities could be a useful measure for local government's policy-making and decision-making processes. It could also allow policy-makers to identify different aspects of a city they could improve. Moreover, they could monitor the performance of the cities overtime in order to identify new changes. It should be noted that benchmarking is not limited to a certain set of factors or aspects, but it can be used in every possible comparison between two entities. Nevertheless, SGS (formerly Société Générale de Surveillance), in its attempt to benchmark some of Pacific Rim cities (Auckland, Wellington, Sydney, Melbourne, Brisbane, and Vancouver) identified a number of dimensions including skilled labor force, innovative capacity, livability, cultural capital, environmental performance, and effective governance (SGSEP, 2009). In this study, employment statistics were used as an indicator of inter-sectorial performance of cities. Thus, this study was an inter-sectorial benchmarking investigation from Taylor's (2011) typology viewpoint.

Most of successful and advanced cities (London and New York e.g.) had a significant distance with Tehran, so there was simply no possibility to make a logical comparison between Tehran and such cities. In this study, Seoul was used as the benchmark. There were some similarities between these two cities providing logical reasons to perform the present benchmarking: 
Tehran and Seoul were sister cities and this was the most important reason to compare them together. They also had a long history of cooperation in terms of urban affairs. For example, Teheranno, the so-called Silicon Valley of South Korea, is a street named after Tehran. Indeed, the other reasons for choosing Seoul as a benchmark for Tehran were listed below:

- South Korea and Iran have started development paths at the same time in the 1960s.

Populations in Seoul and Tehran are almost equal.

- Municipal areas in Seoul and Tehran are approximately equal $\left(686 \mathrm{~km}^{2}\right.$ for Seoul and $605 \mathrm{~km}^{2}$ for Tehran).

So, this study had a closer look at Seoul with a global scale compared with Tehran. Then, the resources and capabilities of these two cities were compared to find the gaps between Tehran and its benchmark city, Seoul.

\section{Comparing Tehran and Seoul}

Tehran's gross domestic product (GDP) in 2017 was about $\$ 100$ billion, whereas Seoul's GDP in 2017 was $\$ 420$ billion (The World Bank, 2017). Tehran's weakness was not limited to the GDP in terms of its comparison with Seoul, but much deeper shortcomings were observed in the domain of workforce makeup. In the following Table (Table 1), workforce makeup in both cities was compared concerning major economic activity groups. These data were shown in the International Standard Industrial Classification of All Economic Activities (ISIC) for major economic activity groups.

\begin{tabular}{|c|c|c|c|c|c|c|}
\hline \multirow{2}{*}{$\begin{array}{l}\text { Major activity } \\
\text { groups }\end{array}$} & \multirow{2}{*}{$\begin{array}{l}2011 \\
\text { Tehran }\end{array}$} & \multirow{2}{*}{\begin{tabular}{|l|}
2014 \\
Seoul
\end{tabular}} & \multicolumn{4}{|c|}{ Share (Percentage) } \\
\hline & & & Tehran & Seoul & $\begin{array}{l}\text { differenc } \\
\mathrm{e}\end{array}$ & Rank \\
\hline $\begin{array}{l}\text { Agriculture, } \\
\text { forestry, and } \\
\text { fishing }\end{array}$ & 22,823 & 214 & $0.9 \%$ & $0.0 \%$ & $-0.9 \%$ & 14 \\
\hline $\begin{array}{l}\text { Mining and } \\
\text { quarrying }\end{array}$ & 22,631 & 652 & $0.9 \%$ & $0.0 \%$ & $-0.9 \%$ & 13 \\
\hline $\begin{array}{l}\text { Manufacturin } \\
\mathrm{g}\end{array}$ & 428,989 & 283,523 & $17.8 \%$ & $6.0 \%$ & $-11.8 \%$ & 19 \\
\hline $\begin{array}{l}\text { Electricity, } \\
\text { gas, and } \\
\text { steam and air } \\
\text { conditioning } \\
\text { supply } \\
\end{array}$ & 18,371 & 7,771 & $0.8 \%$ & $0.2 \%$ & $-0.6 \%$ & 12 \\
\hline $\begin{array}{l}\text { Water supply, } \\
\text { sewerage, and } \\
\text { waste } \\
\text { management } \\
\text { and remediation } \\
\text { activities } \\
\end{array}$ & 10,175 & 6,788 & $0.4 \%$ & $0.1 \%$ & $-0.3 \%$ & 11 \\
\hline Construction & 174,255 & 283,226 & $7.2 \%$ & $6.0 \%$ & $-1.2 \%$ & 15 \\
\hline
\end{tabular}

ISSN-Print: 2007-1582- ISSN-On line: 2007-3682 ECORFAN $^{\circledR}$ All rights reserved.

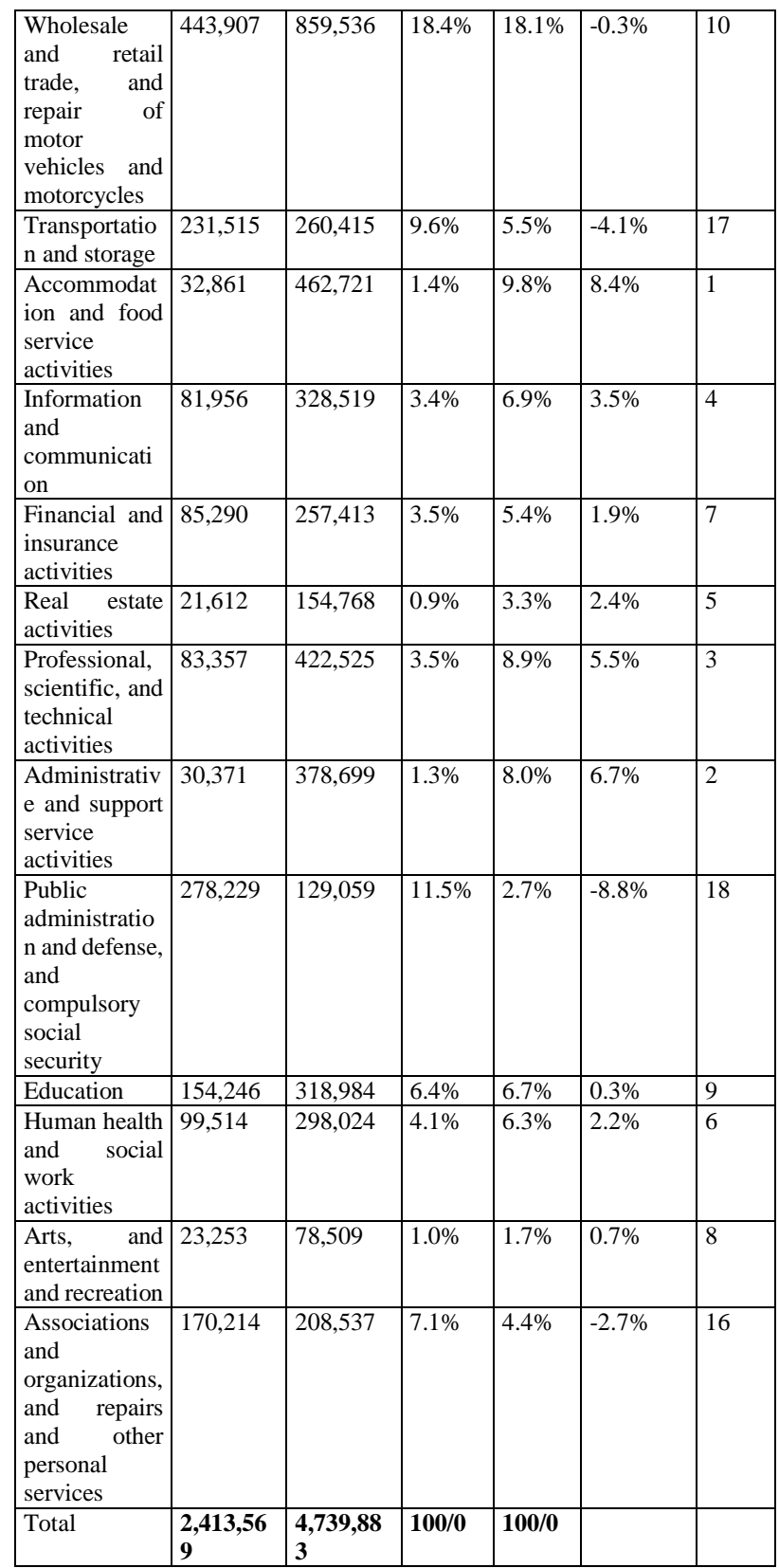

Table 1 Major economic activity groups in Tehran and Seoul

Sources: Statistics Korea, 2014; Statistical Center of Iran, 2011

The first point worth noticing was that data from both cities were actually slightly different in terms of the time being released. The data for Tehran were based on the last nationwide census taken in 2011; whilst, those for Seoul were based on its workforce statistics released in 2014 by Statistics Korea yearbook. Indeed, in this Table, the workforce in both cities was divided into 19 activity groups (based on the ISIC Rev.4). The total population of Tehran at the time of data collection was 8.2 million, while the total population of Seoul was about 10 million. As well, the employed population in Tehran was about 2.4 million while that was reported 4.7 million in Seoul. Furthermore, the participation ratios were $44 \%$ and $38 \%$ in Seoul and Tehran; respectively.

PADASH, Hamid, EBRAHIMZADEH, Mehdi and KHODAPANAH, Bahman. Benchmarking a sister city: Identifying value-adding activities in Tehran compared to Seoul. ECORFAN Journal-Mexico. 2019. 
The radar chart presented in chart 1 compared employment status within both cities considering the economic activity groups in the best way. Indeed, this chart was based on the percentage of employment by the given activity groups from the total employment.

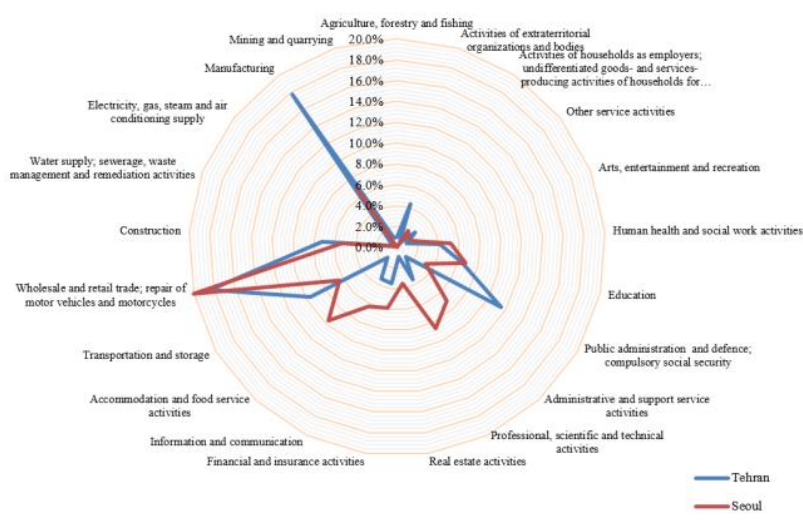

Chart 1 Radar chart comparing economic activity groups in Seoul and Tehran

This chart showed that the pattern of employment distribution in various activity groups for both cities was very similar. This could be another reason why Seoul was chosen as the best benchmark city for Tehran. But, there were some differences between these two cities, a fact that needed more contemplation.

As can be seen in chart 1 and table 1 , there were distances between these two cities in terms of workforce makeup. Comparing the percentage of every activity group in both cities, seven major activity groups were identified revealing that Tehran had much distance from its benchmark city, Seoul. These activity groups, listed below, entailed $48 \%$ of employment in Seoul; whilst, they only accounted for $18 \%$ of employment in Tehran. These groups were as follows:

1. Accommodation and food service activities

2. Administrative and support service activities

3. Professional, scientific, and technical activities

4. Information and communication activities

5. Real estate activities

6. Human health and social work activities

7. Financial and insurance activities

Indeed, it seems that Tehran's economic policy-makers ought to focus much more on these seven activity groups. According to the statistics, these activity groups can actually have a major economic power.

ISSN-Print: 2007-1582- ISSN-On line: 2007-3682 ECORFAN $^{\circledR}$ All rights reserved.
Accordingly, each of these activity groups in both Seoul and Tehran were analysed with more detailed information. In general, investment is one of the macroeconomic variables that can play a significant role in promoting the country's economic goals and achieving higher economic growth and development. Basically, since investors are seeking to make profits, they are looking for market that has a low investment risk and, grater profit. On the other hand, most developing countries depends on capital mobility from low productive to more productive sectors. In general, capital mobility is one of the vital sources of growth and development of nations (Edwards, 2001).

\section{Accommodation and Food Service Activities}

According to chart 2, the contribution of tourism and travel to global economy was nearly $\$ 8$ trillion in 2017 employing over 107 million people directly and 125 million people indirectly in tourism- and travel-related jobs. The increasing share of tourism in world economy, over $\$ 11$ trillion by 2027 , also indicated the increasing importance of this industry for global economy (World Travel and Tourism Council: WTTC, 2017).

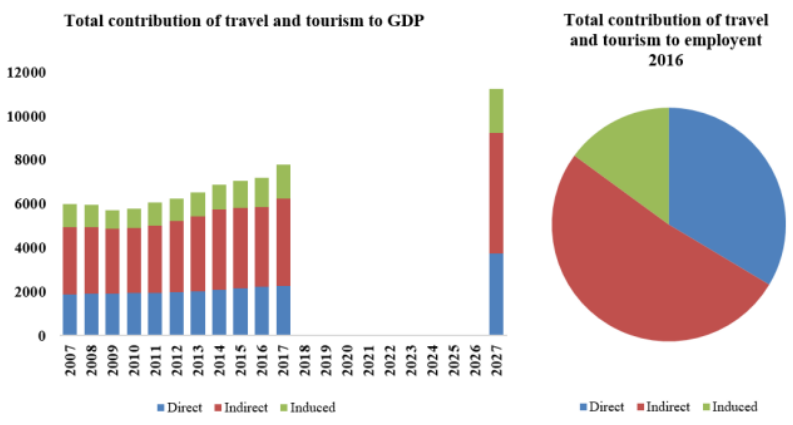

Chart 2 Total contribution of travel and tourism to global GDP and employment

According to the WTTC, tourism industry has created over 277 million jobs over the period of 2007-2017, i.e. one in eleven jobs in the world is related to travel and tourism. This council has also reported that, in the recent years, tourism sector and the main economic sectors such as motor vehicle, finance, and healthcare have shown high growth rates, a situation that will continue years ahead. In 2014, tourist attraction in countries has also reached to 1.14 billion people in total (ibid). 
In 2015, nearly 13 million foreign visitors entered South Korea, while it was reported by 14.5 million visitors in 2014 (Visitkorea, 2016). In 2014 , the direct contribution of tourism to Korean economy was about $2 \%$, while its total contribution was $5.8 \%$ in the same year (WTTC, 2015).

Visitors from emerging economies share $46 \%$ of the world total foreign tourist visits in 2013, which is a tremendous increase from 2000 with $38 \%$ share. According to the WTTC, nearly 476 thousand jobs in 2015 were directly related to tourism industry in Iran (about $1.8 \%$ of the total employment). These jobs included working in hotels, travel agencies, airlines, and other commuting systems (WTTC, 2016). Also, This data reflected the economic activities created by such institutions. Travel and tourism sector's share in the domain of national output was 294 trillion rials, $2.5 \%$ of the total output in 2015 and there was a forcast that it would rise by $6.7 \%$ in 2016. However, Iran stands in 135th of global ranking in terms of the contribution of the given sector to the GDPs of countries. The contribution of travel and tourism to Iranian economy will also rise by $4.9 \%$ anually from 2016 to 2026 , then it will reach to $2.8 \%$ of the total output.

The WTTC has also emphasized that travel and tourism sector, in addition to its direct contribution, can also have an indirect contribution to national economies. So, the total contribution of this sector is the sum of its direct and indirect contributions. According to the WTTC, the total contribution of this sector to Iranian economy in 2015 was 793 trillion rials, equivalent to $6.7 \% \mathrm{t}$ of the GDP, and it was estimated to rise by $5.9 \%$ in 2016 .

In addition, estimates suggested that the total contribution of this sector to Iranian GDP would also rise by $4.7 \%$ annually and reach to 1334 trillion rials by 2026 (7.3\% of the GDP) (WTTC, 2016). It is worth mentioning that Iran is a Muslim country and there is opportunity to tourism attraction from Muslim countries. Demands for halal products and services have increased with the development of tourism and the geographical mobility of tourists. The provision of halal items for travellers from the world's 52 Muslim countries would provide a competitive advantage for destinations targeting this segment of tourism (Olya \& Al-ansi, 2018)

\section{Administrative and Support Service Activities}

Since becoming the capital city, Iran's political and governmental system has been intensively housed in Tehran. In fact, all socio-economic activities have been placed in Tehran from 1956 through relying on incomes from crude oil and this city has become the center of decisionmaking and policy-making at macro-levels and establishing governmental bodies. Furthermore, most of companies have established their headquarters in Tehran and many of them have also placed their factories in this city as well. In fact, Tehran has become the sole economic center of Iran holding most of the Iranian businesses in it (Central Bank of Iran, 2016). However, figure 1 showed the ratio of land use from administrative activities to other uses among different municipal districts of the city. This map was retrieved from the latest version of the Atlas of Tehran Metropolis (2006).

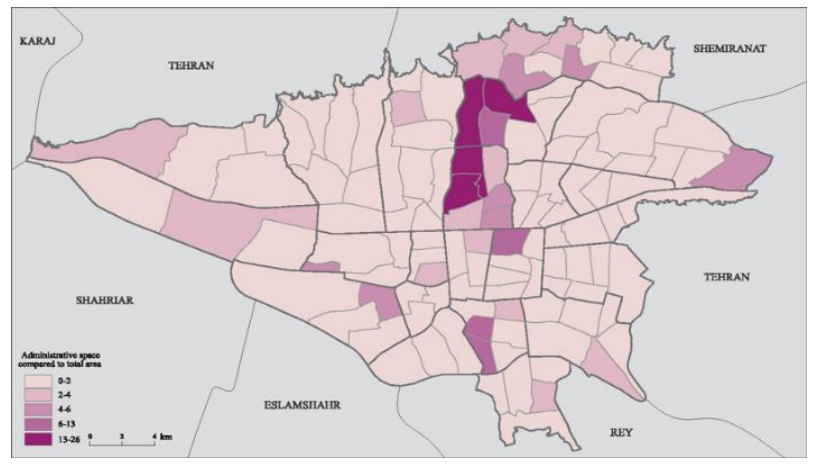

Figure 1 Ratio of land use from administrative activities to other uses in Tehran

As illustrated in figure 1 , districts in the center of the city had the highest ratios in contrast to other districts, mostly because they were somehow older than other districts (Tehran Municipality, 2006).

\section{Professional, Scientific, and Technical Activities}

The European Union-28's (EU-28's) professional, scientific, and technical activity sector (NACE Section M) numbered some 245 thousand enterprises in 2014, employing 12.1 million individuals generating EUR 667.5 billion of value-added. The contribution of this sector to the non-financial business economy was $18.2 \%$ of the enterprise population, $8.9 \%$ of the workforce, and $10.1 \%$ of the value- added (Eurostat, 2018). 
It should be noted that labour productivity of the EU-28's professional, scientific, and technical activity sector in 2014 was EUR 55 thousand per person employed, that was slightly above the non-financial business economy average of EUR 48.5 thousand per person employed. Along with this high labour productivity; average personnel costs within the professional, scientific, and technical activity sector were EUR 45.3 thousand per employee, which was above the average for the nonfinancial business economy that was EUR 33.3 thousand per employee (Eurostat, 2018).

While professional, scientific, and technical activities could contribute to $3.5 \%$ of the workforce in Tehran, its contribution to the workforce in Seoul was $8.9 \%$, just the same as that in the EU. This figure revealed a big gap in the domain of workforce formation between Tehran and Seoul.

\section{Information and Communication Activities}

Recently, all countries have started to invest in information and communication technology (ICT) sector, because they have realized the significant role of ICT in socioeconomic stability (Avgerou, 2010). In fact, investment in ICT is considered as one of the main drivers of economic development in emerging and developed countries (Thompson, 2008).

With an increasing speed, the ICT sector (including computer hardware and software, network services, electronic device manufacturing, etc.), can also play a key role in global economy (Voda, \& Radu, 2018). According to the data released, 5\% of gross world product (GWP) between 2003 and 2008 has come from ICT sector (Beardsley, Enriques, Bonini, Sandoval, \& Brun, 2010). In 2008, these figures have risen to $5.4 \%$ and there is a forecast that they would reach to over $8.7 \%$ by 2020 . Because of its production size and nature, ICT sector can play a significant role in economic growth. Also, thanks to its unique nature, ICT can have a leading role in the production of nearly all other goods and services. Following the development of technologies like the Internet and its related affiliates, ICT is able to make businesses become familiar with the business environment and be more efficient within a whole process for the benefit of these businesses and the rest of the economy.

ISSN-Print: 2007-1582- ISSN-On line: 2007-3682 ECORFAN $^{\circledR}$ All rights reserved.
According to McKinsey, mobile broad band penetration to emerging markets can also have a potential of creating incomes by $\$ 300$ to 420 billion. In addition, it can account for 7 to $10 \%$ of jobs (directly and indirectly) in related industries.

In 2016, Iran's ICT industry output was $\$ 21$ billion and it was estimated that it will rise to $\$ 30$ billion by 2020 (Ministry of Communication \& Information Technology Iran, 2017).

\section{Real Estate Activities}

Economic activities of any type in each region can have their own direct and indirect benefits. Some of these activities can be defined in real estates. It is also clear that investment in real estate sector can induce growth and increase economic power of cities ( Munja, Bhide, \& Kolli, 2014). In fact, real estate is considered as one of the biggest investment areas in an economy; i.e. approximately 2 to $8 \%$ of world output comes from real estates and it also absorbs 10 to $30 \%$ of global investment expenditure (Ghaderi, Eslamloueyan, \& Owjimehr, 2011). In some cities like Singapore and Hong Kong, real estate also plays a significant role in economy due to its scarcity to businesses located in these cities (Haila, 2000).

In Iran, investments in real estates have grown by $11.2 \%$ annually over the last decade. Some of the factors affecting the amount of investment in real estates are real estate price index, instruction cost, liquidity, and household income. Moreover, other factors which can indirectly influence investment in real estates are shares and deposits in which rises in prices (interest rate in the case of deposits) can lead to a decline in investment in real estates (ibid). As well, investments in real estates can have their own impacts on many aspects of economy. Literature on this topic has also shown that value-added in this industry does not solely belong to real estate businesses, but it also goes to many other industries.

According to Tehran Real Estate Market monthly report, the total real estate transactions in March 2016 was 5918 incidents indicating a relatively $20 \%$ increase from the same period of time in 2015. The average housing price index was also reported by $\$ 1000$ for $1 \mathrm{~m}^{2}$ housing space, revealing a 5\% increase from March 2015 (Central Bank of Iran, 2016).

PADASH, Hamid, EBRAHIMZADEH, Mehdi and KHODAPANAH, Bahman. Benchmarking a sister city: Identifying value-adding activities in Tehran compared to Seoul. ECORFAN Journal-Mexico. 2019. 


\section{Human Health and Social Work Activities}

According to hall and Nguyen (2018), public spending in the economy has not stifled economies, but fundamentally is associated with economic growth. One of the biggest components of household expenditures is healthcare. According to a report on healthcare expenditure in 2013, healthcare spending in the Organisation for Economic Cooperation and Development (OECD) member countries can contribute to $9.3 \%$ of the GDP (OECD, 2015).

Similarly, Eurostat (2017) reported that the level of current healthcare expenditure in Germany was $€ 321$ billion in 2014 - the highest value among the EU member states - equivalent to $11 \%$ of the GDP for 2014. France also recorded the second highest level of current healthcare expenditure ( $€ 237$ billion), followed by the United Kingdom (€223 billion) (Eurostat, 2017). The contribution of healthcare expenditure to the GDP in Iran has been also reported by $6.9 \%$ in 2014 , while it was $7.4 \%$ for the same year in South Korea (The World Bank, 2014). Since health care has been known as a key component of any industrialized economy ( Squires, 2012).

Developing countries like Iran tries to develop its capabilities in drug and health section. Hence, this needs for highly skilled workers which leads to a rise in healthcare expenditure. Being the centre of medical care sector in Iran; Tehran has the highest and the most advanced number of hospitals and clinics. So, it is endowed with national potentials to expand its healthcare industry.

\section{Banking and Financial Services}

Recent studies on financial sector show its positive role in enhancing growth rate of economies in developing countries. In fact, financial sector can increase local and foreign investment and consequently empower financial competitiveness of these countries (Sharman, 2010). According to the latest ranking of world financial centers, Seoul was reported as the 7 th biggest financial center of the world, jumping 3 steps from its previous rank in 2014 which was 10th (Global Financial Center , 2015).
Today, it is assumed that financial sector, especially insurance activities, can play a major role in economic growth and prosperity. Therefore, describing how insurance affects economic growth and identifying the link between insurance and growth rate are really important for policy-making. On the one hand, insurance is a financial institution enhancing economic power of nations, and on the other hand, it can provide the basis for the expansion of economic activities by creating assurance. In other words, insurance companies can create financial stability and reduce uncertainty by recovering business losses. They are also considered as very close successors for government compensation programs. Another point is that, insurance companies help to better allocate economic resources by their investment activities (Jafari \& Kardgar, 2007).

Financial development by various channels can also help in enhancing economic growth. These channels include diversifying the risk, reducing liquidity risk, as well as reducing information asymmetry between loaners and borrowers. Moreover, financial institutions can have an effect on investment decisions and economic growth by six functions; reduction in search costs for potential investment opportunities, practice of corporate governance, risk diversification and management, integration of savings, exchange of products and services, as well as reduction of casual shocks on investments.

These functions can aid in reducing exchange costs in liquidity risk preference and fix market failure and consequently increase economic growth rates by better allocation of resources. Furthermore, insurance companies can mobilize individual savings and direct them to the businesses in need (Mirzaei, Hasani, \& Nooreddini, 2015).

According to Tehran's Planning and Employment Association, in March 2014, the total non-governmental banking deposits in Tehran was indicated in Table 2 (Departmant of Planing and Employment of Tehran Province, 2014). 


\begin{tabular}{|l|l|l|l|}
\hline Type & \multicolumn{1}{|c|}{$\begin{array}{l}\text { Amount } \\
\text { (trillion } \\
\text { Iranian } \\
\text { rials) }\end{array}$} & $\begin{array}{l}\text { Changes } \\
\text { in } \begin{array}{l}\text { (\%) } \\
\text { month }\end{array}\end{array}$ & $\begin{array}{l}\text { Changes } \\
\text { in last six } \\
\text { months } \\
(\%)\end{array}$ \\
\hline Private-sector deposits & 2000 & 6.4 & 33.6 \\
\hline Checking deposits & 502 & 10 & 59.6 \\
\hline Non-checking deposits & 1498 & 5.2 & 26.7 \\
\hline Savings deposits & 61 & -7.6 & -45.9 \\
\hline Investment deposits & 1437 & 5.9 & 34.4 \\
\hline $\begin{array}{l}\text { Short-term investment } \\
\text { deposits }\end{array}$ & 647 & 9.4 & 28 \\
\hline $\begin{array}{l}\text { Long-term investment } \\
\text { deposits }\end{array}$ & 789 & 3.1 & 40.2 \\
\hline
\end{tabular}

Table 2 Banking deposits in March 2014 in Tehran Source: Departmant of Planing and Employment of Tehran Province, 2014

As can be seen in Table 2, private-sector deposits (checking and non-checking) and investment deposits (short-term and long-term) had increased dramatically over the last onemonth and the six-month period (related to March 2014). In contrast, savings deposits showed a severe decrease in these periods. One reason for this was the worsened economic situation in that period of time plus the increase in interest rates in private-sector and investment deposits, while the savings deposits had actually zero interest. In the following Table (Table 3), statistics of insurance industry in Tehran were retrieved from insurance industry yearbook released in 2016. In Table 3, some indices of insurance sector both in Iran and South Korea, as well as the world over, were illustrated (Central Insurance of Iran, 2016).

\begin{tabular}{|l|l|l|l|}
\cline { 2 - 4 } \multicolumn{1}{c|}{} & Iran & \multicolumn{1}{c|}{$\begin{array}{l}\text { South } \\
\text { Korea }\end{array}$} & World \\
\hline $\begin{array}{l}\text { Total insurance premium } \\
\text { (million dollars) }\end{array}$ & 7554 & 153620 & 4641000 \\
\hline $\begin{array}{l}\text { Per capita insurance } \\
\text { premium (dollars) }\end{array}$ & 96 & 3034 & 621 \\
\hline $\begin{array}{l}\text { Insurance penetration } \\
\text { (percent) }\end{array}$ & 2.08 & 11.42 & 6.23 \\
\hline
\end{tabular}

Table 3 Insurance industry indices in 2015

According to Table 3, Iranian insurance sector was well behind South Korea and even world average, since premium per capita for Iran was about one-seventh of the world average premium. Comparing with South Korea, this index was much less and it was only $3 \%$. Indeed, there was a tremendous need for developing this sector in Iranian economy. Possibly, the premium difference between these two countries could be related to differences in both of their GDPs and populations, but the important case was that insurance penetration in Iran was less than one-sixth of that in South Korea.
Indeed, these data showed the necessity of developing this sector in Iranian economy. Insurance premium paid in Tehran was 62.7 trillion rials accounting for $38 \%$ of the total premium in Iran. So, it was concluded that Tehran was home to $38 \%$ of insurance market of Iran (Central Insurance of Iran, 2016). Table 4 showed the market share for the 8 biggest insurance companies in Tehran's insurance market.

\begin{tabular}{|l|l|l|}
\hline Company & \multicolumn{1}{|l|}{$\begin{array}{l}\text { Share of premium } \\
\text { paid (billion rials) }\end{array}$} & $\begin{array}{l}\text { Share of premium } \\
\text { paid percentage) }\end{array}$ \\
\hline $\begin{array}{l}\text { Iran Insurance } \\
\text { Corporation }\end{array}$ & 27330 & 43.6 \\
\hline $\begin{array}{l}\text { Asia Insurance } \\
\text { Corporation }\end{array}$ & 5400 & 8.6 \\
\hline $\begin{array}{l}\text { Parsian Insurance } \\
\text { Corporation }\end{array}$ & 4437 & 7.1 \\
\hline $\begin{array}{l}\text { Dana Insurance } \\
\text { Corporation }\end{array}$ & 3760 & 6 \\
\hline $\begin{array}{l}\text { Alborz Insurance } \\
\text { Corporation }\end{array}$ & 3570 & 5.7 \\
\hline $\begin{array}{l}\text { Kosar Insurance } \\
\text { Corporation }\end{array}$ & 2820 & 3.5 \\
\hline $\begin{array}{l}\text { Sina Insurance } \\
\text { Corporation }\end{array}$ & 2190 & 3.3 \\
\hline $\begin{array}{l}\text { Kar Afrin } \\
\text { Insurance } \\
\text { Corporation }\end{array}$ & 2070 & \\
\hline
\end{tabular}

Table 4 Share of companies in Tehran's insurance market Source: Central Insurance of Iran (2016)

According to the data provided in Table 4, $43 \% \mathrm{t}$ of Tehran's insurance market was dominated by Iran Insurance Corporation making it a market leader. Other companies' market share was reported less than $10 \%$.

\section{Conclusions and Policy Recommendations}

The purpose of this study was to identify valueadding activities in Tehran through a benchmarking approach. In this regard, considerable similarities were found between Tehran and Seoul as politically sister cities. The indicators used in the present study to compare Tehran with Seoul were also based on the data related to major economic activity groups (based on the ISIC). The results revealed that the economic activity groups in Tehran were different from those of its counterpart. There was also a focus on activity groups showing the biggest gaps in the comparison between Seoul and Tehran and seven activity groups were then chosen in this regard including accommodation and food service activities, administrative and support service activities. 
Professional, scientific, and technical activities, information and communication activities, real estate activities, human health and social work activities, as well as financial and insurance activities. Then, each of these activity groups was discussed separately in order to identify their roles in the economy. Not surprisingly, these activity groups, related to their respected industries, had major roles in national and global economy. Their contributions to national GDP were also dramatic.

According to political economists, the neoclassical economic growth theory could be stated by a general equation in which it is supposed that GDP is affected by the production factors used, that is, labour force, capital, their productivity and institutions. These economists, specially, focus on natural conditions, government and international relationships.

Later, many theoreticians, particularly those who had been brought up under the neoclassical tradition, ignored the importance of institutions in the process of economic growth. However, many studies, published during the last two decades, have once again confirmed the importance of institutions as the supporting factors of economic growth.

In other words, capital mobility from a section to another depends on institutional environment of every country. Fundamental elements of institutional framework for capital mobility are sectoral regulatory systems, tax regulations and government policies. Therefore, it can be concluded that Tehran could claim a much better stance in the network of global cities by engagement of all economic actors and improving mentioned activities.

Moreover, Tehran's policy-makers were recommended to have a special focus on these activity groups. Also, it was suggested to monitor these activity groups on a yearly basis in order to track the changes. Indeed, Tehran could approach to its real stance in the network of global cities by reflecting on these activities and improving them to fill the gaps between itself and its benchmark city.

\section{Research Limitations}

All research studies can have their own limitations. One of the main limitations to this research was lack of previous studies about benchmarking cities using their economic sectors and the second limitation was related to statistical differences in specific periods for both cities. It should be noted that these limitations could influence the study results, but they could not change the main findings.

\section{References}

Atkinson, R., \& Wu, J. (2017). The 2017 State New Economy Index: Benchmarking Economic Transformation in the States.

Ahmed, S. U. (2018). Dacca: A study in Urban History and Development (Vol. 1). Routledge.

Avgerou, C. (2010). Discourses on ICT and development. Information Technologies \& International Development, 6(3), pp-1.

Beardsley, Enriques, L., Bonini, S., Sandoval, S., \& Brun, N. (2010). Fostering the Economic and Social Benefits of ICT. World Economic Forum - The Global Information Technology Report.

Bhowmik, S. (2012). Street Vendors in the Global Urban Economy. Taylor \& Francis.

Bontje, M., Musterd, S., \& Sleutjes, B. (2017). Skills and cities: Knowledge workers in Northwest-European cities. International Journal of Knowledge-Based Development, 8(2), 135-153.

Business Dictionary. (2017). Benchmarking. Retrieved from: http://www.businessdictionary.com/definition/b enchmarking.html

Capello, R. (2011). Location, regional growth, and local development theories. Aestimum, (58), 1., 1-25.

Caragliu, A., Del Bo, C., \& Nijkamp, P. (2011). Smart cities in Europe. Journal of Urban Technology, 18(2), 65-82.

Central Insurance of Iran. (2016). Insurance Industry Statistical Yearbook 2015. Central Insurance of Iran. Tehran. 
Departmant of planing and employment of Tehran province. (2014). Economic, Social, and Cultural Indices for Tehran Province - 2014(Q1) (in Persian). Tehran: Departmant of Planing and Employment of Tehran Province.

Dick, E., \& Narang, A. (2005). Canadian urban benchmark distribution systems. Report CETCVarennes, 121.

Evans, G. (2009). Creative cities, creative spaces, and urban policy. Urban Studies, 46(56), 1003-1040.

Eurostat. (2017). Healthcare expenditure statistics. Retrieved from Eurostat.eu: http://ec.europa.eu/eurostat/statistics-

explained/index.php/Healthcare_expenditure_st atistics.

Eurostat. (2018). Professional, scientific, and technical activity statistics - NACE Rev. 2. Retrieved from Eurostat.eu: http://ec.europa.eu/eurostat/statistics-

explained/index.php/Professional,_scientific_an d_technical_activity_statistics_-

_NACE_Rev._2

Floater, G., Rode, P., \& Robert, A. K. (2014). Cities and the new climate economy: The transformative role of global urban growth. New Climate Economy Cities Paper 01. LSE Cities. London School of Economics and Political Science.

Ghaderi, J., Eslamloueyan, K., \& Owjimehr, S. (2011). Economic determinants of housing investment in Iran. The Economic Research, 4770.

Haila, A. (2000). Real Estate in Global Cities: Singapore and Hong Kong as Property States. Urban Studies, 2241-2256.

Hall, D., \& Nguyen, T. A. (2018). Economic benefits of public services. Real-world economics review, 100.

Healey, P. (2008). Creativity and urban governance. Policy Studies 25:2, 87-102.

Henderson, J. (2010). Cities and development. Journal of Regional Science, 50(1), 515-540.

Iran Central Bank. (2016). Tehran Real Estate Market Report (March 2016). Tehran: Central Bank of Iran.

ISSN-Print: 2007-1582- ISSN-On line: 2007-3682 ECORFAN $^{\circledR}$ All rights reserved.
Jafari, A., \& Kardgar, E. (2007). Does development of Insurance sector enhance economic growth? The Economic Research, 1739.

Kulenovic, Z.J. and Cech, A. (2015). Six case studies of economically successful cities. The World Bank. Retrieved from https://openknowledge.worldbank.org

Kirkby, R. J. (2018). Urbanization in China: Town and Country in a Developing Economy 1949-2000 AD (Vol. 3). Routledge.

Kearney, A. T. (2016). Global cities in 2016. Retrieved from https://www.atkearney.com/documents/10192/8 178456/Global+ Cities.

Meares, C., Owen, P., Murray, C., Mohammadzadeh, M., \& Rohani, M. (2015). City Benchmarking - An Overview of Auckland's Rankings in the Global Context. Auckland: Auckland Council Technical Report.

Mehrara, M., \& Rezaei, S. (2015). The Determinants of Economic Growth in Iran Based on Bayesian Model Averaging. International Letters of Social and Humanistic Sciences. vol(49), 1-11.

Ministry of Comuinication and Information Technology. ICT Industry Output. MCIT (in Persian) (2017). Retrieved from https://www.ict.gov.ir/fa/news

Mirzaei, A., Hasani, M., \& Nooreddini, S. S. (2015). The impact of insurance indices on economic growth among OPEC countries using dynamic panel model through GMM method. Insurance Researches (in Persian), 1-22.

OECD. (2015). Focus on Healthcare 2015. Retrieved from www.oecd.org/health/healthsystems/Focus-Health-Spending-2015.pdf:

OECD.

Olya, H. G., \& Al-ansi, A. (2018). Risk assessment of halal products and services: Implication for tourism industry. Tourism Management, 65, 279-291.

O'sullivan, A. (2007). Urban economics. McGraw-Hill/Irwin.

PADASH, Hamid, EBRAHIMZADEH, Mehdi and KHODAPANAH, Bahman. Benchmarking a sister city: Identifying value-adding activities in Tehran compared to Seoul. ECORFAN Journal-Mexico. 2019. 
Pierre, J. (2016). Partnerships in urban governance: European and American experiences. (J. Pierre, Ed.) Springer.

SGSEP. (2009). Improving city performance through benchmarking. International Cities, Town Centers and Communities Conference. Retrived from http://www.sgsep.com.au/assets/SGS-Urbecon1-2009.pdf.

Sharman, J. (2010). International financial centers and developing countries providing institutions for growth and poverty alleviation. Commonwealth Secretariat, 1-41.

Sunley, P., Martin, R., \& Tyler, P. (2017). Cities in transition: Problems, processes, and policies. Cambridge Journal of Regions, Economy and Society, 10(3), 383-390.

Sriram, V., Mersha, T., \& Herron, L. (2007). Drivers of urban entrepreneurship: An integrative model. International Journal of Entrepreneurial Behavior \& Research, 235-251.

Sassen, S. (2018). The global city: Strategic Site, New Frontier. In Moving Cities - Contested Views on Urban Life (pp. 11-28). Springer VS, Wiesbaden.

Thompson, M. (2008). ICT and development studies: Towards development 2.0. Journal of International Development, 20(6), 821-835.

Taylor, Z. (2011). Lies, damned lies and statistics. Torento, Canada: Research Report Prepared for the Intergovernmental Committee for Economic and Labour Force Development.

Tehran Municipality. (2006). Atlas of Tehran Metropolis. Terhan Municipality. Retrieved from

http://atlas.tehran.ir/Default.aspx?tabid=318

Trettin, L., \& Welter, F. (2011). Challenges of spatially oriented entrepreneurship research. Entrepreneurship \& Regional Development, 23(7-8), 575-602.

Visitkorea. (2016). Korea, Monthly Statistics of Tourism. Retrieved from visitkorea: http://kto.visitkorea.or.kr/eng/tourismStatics/ke yFacts/KoreaMonthlyStatistics/eng/inout/inout. kto?func_name $=3$.
Voda, A. I., \& Radu, L. D. (2018). Investigating economic factors of sustainability in European smart cities. European Journal of Sustainable Development, 7(1), 107-120.

Wiewel, W., \& Perry, D. (2015). Global Universities and Urban Development: Case Studies and Analyses. Routledge.

Wojcik, D. (2018). The New Oxford Handbook of Economic Geography. Oxford : Oxford University Press.

World Bank. (2014). Health expenditure, total (\% of GDP). Retrieved from worldbank.org: http://data.worldbank.org/indicator/SH.XPD.T OTL.ZS

WTTC. (2015). Economic Impact 2015 South Korea. Retrieved from www.wttc.org: https://www.wttc.org/-

/media/files/reports/economic\%20impact\%20re search/countries\%202015/southkorea2015.pdf

WTTC. (2016). Travel \& Tourism Economic Impact 2016 Iran. World Travel and Tourism Council.

WTTC. (2017). The Economic Impact of Travel \& Tourism March 2017. World Travel and Tourism Council. 